\title{
Developing Culinary Tourism: The Role of Traditional Food as Cultural Heritage in Bali
}

\author{
Ni Wayan Sukerti ${ }^{1 *}$ Cokorda Istri Raka Marsiti ${ }^{2}$ \\ ${ }^{1,2}$ Family Welfare Education Department, Engineering and Vocational Faculty, Ganesha University of Education \\ 81116, Bali, Indonesia \\ Corresponding author's: wayansukerti71@yahoo.com,
}

\begin{abstract}
Bali as a tourist destination has a diversity of cultures, one of which is culinary arts that needs to be preserved in the current era of globalization. The purpose of this study is to describe: 1) the culinary classification of Bali; 2) material structure; 3) Balinese special spices; 4) examples of dishes in the Balinese culinary festival according to classification. This type of research is a survey. Data was collected by observation and documentation. Located in Buleleng Regency, and analyzed descriptively. The results showed: 1) the culinary classification of Bali consisted of main food, coconut milk dishes, other food dishes, non-food dishes, wet snacks, dry snacks, complementary dishes, and beverages; 2) special culinary ingredients of Bali consisting of rice, corn, cassava, pork, chicken, seafood, freshwater fish, duck, various types of vegetables; 3) typical Balinese culinary spices with the term base genep even consisting of various herbs and spices with a certain composition.4) Examples of dishes in the Balinese culinary festival according to classification: interrupted Nasi Sela, bubuh mengguh, belayag, entil, jukut ares, betutu, sate lilit, lawar, jaja laklak, jaje bendu, jaja sumping,jaja gintil, jaja klepon, sambal bongkot, sambal matah, sambel mbe, rujak kuud, es daluman, es bir. Balinese cuisine remains sustainable after being socialized through a culinary arts festival that is held regularly once a year by all regency governments in Bali.
\end{abstract}

Keywords: culinary tourism, traditional food, Bali Heritage

\section{INTRODUCTION}

It is only fitting that the development of gastronomy tourism beside cultural tourism in Bali region which is often visited by domestic and foreign tourists is supported with the document of the repertoire of special Balinese culinary. They will enjoy the serving of the types of food, types of serrving and types of ingredients and unique tastes, so that these can make them satisfied with the tastes and their gastronomical needs and become remembrance. Thus their visit to Bali is not only caused by the beauty of the nature, but also because of the enchantment and the variety of the culinary. However, the fact now shows that Balinese traditional food is rarely served in the hotel and restorant industry .

Not many traditional restaurants that specially serve special Balinese traditional food. It is pointed out that this is caused by the lack of information about the repertoire of Balinese food, the scarcity of recipe books of Balinese special food, so that a few people can serve Balinese food specialty, such as the combination of ingredients which are without special measurement can produce ingredients that are rich which are generally prepared by men as juru patus. tukang lawar ( persons who lead others in food processing (Suandra, 1972)

In addition, children and adolescents are less interested in Balinese traditional food. This is caused by the growing number of fast food restaurants, food stalls that sell food fusion or modified food, which is more favorite among the adolecents. If this condition is not controlled, it can result in the loss of Balinese traditional food, which is the legacy that is passed from generation to generation, which is one of the assets that needs to be preserved. The limited source of knowledge on the recipes of Balinese food specialty in the form of recipe books motivated the researchers to investigate this problem, by adopting the very fast growing information and technological advancement. This study is a strategy of information technology-based Balinese food development in which the recipes that have been taught from generation to generation were collected, identified, and tried out. Then, based on the standard recipes, the researchers wrote a book, and also a media in the form of a special website of Balinese special food recipes.

The effort at preserving the culinary art is not only limited to the holding of various food festivals which last for some days. However, the strategy to socialize culinary as an obligation for Balinese community has almost been neglected. With the advancement in science, 
technology and art as seen today, in which the youth in Bali , starting from children to adolescents, rarely like Balinese traditional food and drink. They tend to like fast food and drink like french fries, which beside the fast speed the taste is delicious and surely it raises one's status. If this condition keeps on the same, Balinese traditional food that is a legacy from the ancestors will disappear, and Bali will lose its identity, especially the uniqueness of its culinary which cannot be separated from the culture (Marsiti, 2005)

As a generation which will carry on the legacy from the Balinese ancestors, the researchers have the obligation to socialize Balinese traditional serving starting from staple food, side dishes, vegetables, a variety of snacks and drinks, by synergizing through the use of information technology in the form of the website-based Balinese traditional recipes. It is expected that Balinese community, especially children and adolescents as the community members who are sensitive to technology are able to access various recipes of Balinese traditional food, and then try them, enjoy the food. Hence, Balinese culinary art will develop and can last long as part of Balinese culture. This is parallel to the opinion of a scholar(Okech.Roselyne, 2014) that one of the key components of the relation between food and tourism is that the promotion of traditional food plays an important role in gastronomy tourism.

The strategy to develop Balinese traditional food will revive or introduce the types of Balinese traditional food. The listing and reclassification of various types of food which are socialized through the internet media are meant to make the Balinese traditional food remain unchanged, unaffected by modernizaion and can be inherited by the next generation. In the process of food processing, starting from the preparation ( cleansing ) until serving the food one should pay attention to cleanliness or hygiene and the nutrient contents. Similarly, at the time of cooking one should pay attention to the fixed temperature so that the food is not overcooked and lose a large amount of vitamins. In addition, in the preparation of food one also has to take note of the temperature.

If the temperature is not correct, it will cause the food to rote easily or to contain bacteria tnat are dangerous to human health. Hence, food processing largely involves knowledge, such as nutition, physics, hygiene, sanitation etc..

According to Candrawati in Sujatha (2001) Balinese traditional food, including Balinese traditional drinks should be sukla ( does not contain diseases) .Our body needs carbohydrate, protein, fat, vitamins, and minerals to support health. But, if the method of processing it is not clean or the persons who process it have misconseptions about the substances, then this will become a boomerang for the health of the human body. Suci defined a local food, including Balinese food as food that is found and processed, served continually from generation to generation and is different from other local food (Marsiti, 2005). Zainal et.al (2010) in the journal entitled "Malaysian Gatronomy Routes as a Tourist Destination" states that globally, the collaboration between food and tourism is reasonably growing, and the development of gastronomy / culinary art as tourism product has become a trend today. Gastronomy tourism plays an important role in introducing local food and at the same time the culture behind the food served, both from the philosophical and social aspects. Gastronomy tourism can also make a tour experience more enjoyable and has the opportunity to make the tourism atmosphere better than what is expected by tourists in serving food according to Gisslen (2004) one needs to pay attention to the appealof the food served. Hence, in serving food that is in the form of individual portion, one must pay attention to balance (the balance between the size of the plate, the main dish, sauce, side dishses/ garnish), Colours ( the balance in color among the main dish, sauce, side dishes / garnish), Shapes ( better food shape), Texture ( food texture can only be proven by touching. There should be a variety of texure in one food and another, Flavour (a variety of food aromas in one dish). Thus, in presenting food the arrangement on the place of presentation is related to visual appeal, efficiency and adaptability. Londono 2012 states the point is not to write sociology orpsycology ofthe car, the point is to drive. Thus, in the context of gastronomy as a tourist attraction that gives benefits economically to the government, society and entrepreneurs, then the effort that has to be made is to cook food that will be offered to the consumers or tourists according to their appetites.

\section{METHOD}

This research belonged to a survey and documentation. The implementation of this study can be viewed from its goal, that is, to dig and understand extensively Balinese traditional serving. The conclusion that was made in the survey applies in a limited way, it is limited to the object that was studied, that was, Balinese special serving. This study was conducted in Buleleng Regency as one of part Bali Province. This location was selected based on the considerations as follows: (1) have a large area, with a variety of traditional Balinese food; (2)has an annual agenda Buleleng festival that features typical Balinese cuisine from various regions in Buleleng.

The method of data analysis used in this research was the descriptive qualitative method, by describing the results of the observation sheet into a sentence naration so that a conclusion could be made.

\section{RESULTS AND DISCUSSION}

Based on the results of the observation, in general Balinese culinary classification consists of main foods, including: nasi tulen, nasi baas barak, pesor, entil, blayag, ketipat, bubuh moreng, mengguh, ;side dish with coconut milk sauce, including: chicken serosob, jukut ares, jukut nangka, side dish Other sauce products, including: jukut jepang, jukut kelor, side dishes not having sauce, lawar, plecing, serombotan, urab, sate lilit, sate plecing, betutu, ikan bakar, tum be pasih, pesan be pasih. wet snacks include: jaja klepon, jaja bantal, jaja sumping, jaja lapis, jaja wajik, jaja roko-roko, jaja cerorot, jaja bendu. dry 
composition.4) Examples of dishes in the Balinese culinary festival according to classification: Nasi sela/moran, bubuh mengguh, belayag, jukut ares, betutu , sate lilit, lawar, jaja bendu, jaje laklak, jaja klepon,jaja sumping, jaje gintil, rujak tibah, es daluman, es kuud,sambal matah,sambal see, sambal bongkot. Balinese cuisine remains sustainable after being socialized through a culinary arts festival that is held regularly once a year by all regency governments in Bali snacks include: jaja matahari, jaja satuh, dodol, iwel, jaja complementary dishes include: sambal matah, sambal mba, sambal bongkot, sambal see. and drinks; loloh cencem, loloh kunyit, loloh don blimbing, es kuud, es daluman, rujak yeh, rujak tibah,rujak kuah pindang , 2) typical culinary ingredients of Bali consisting of rice, corn, cassava, pork, chicken meat, sea fish, freshwater fish, duck, various types of vegetables; 3) Balinese culinary special spices with the term base genep even consisting of various wet, dry and spices with a certain

The following are the types or classification of Balinese food presented in a table below:

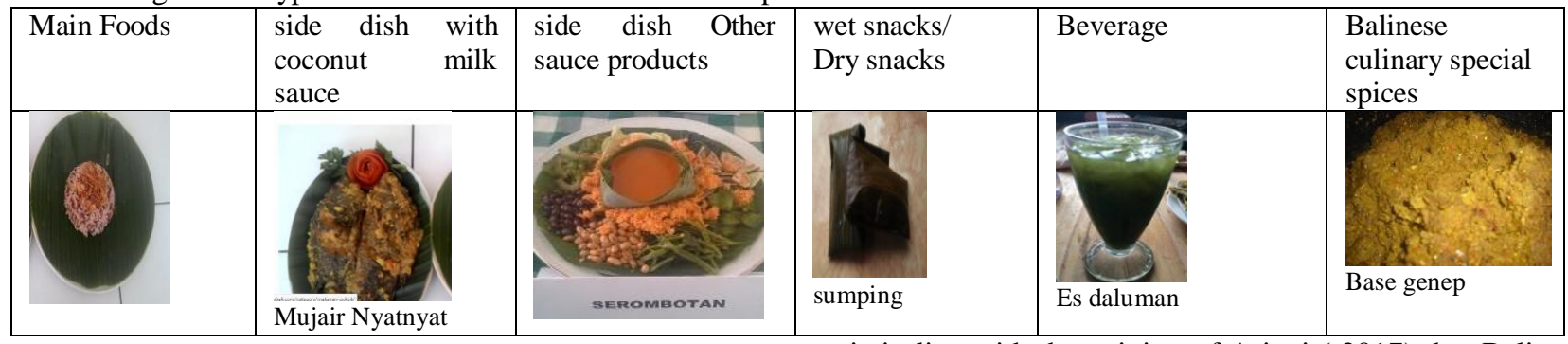

is in line with the opinion of Ariani ( 2017) that Balinese

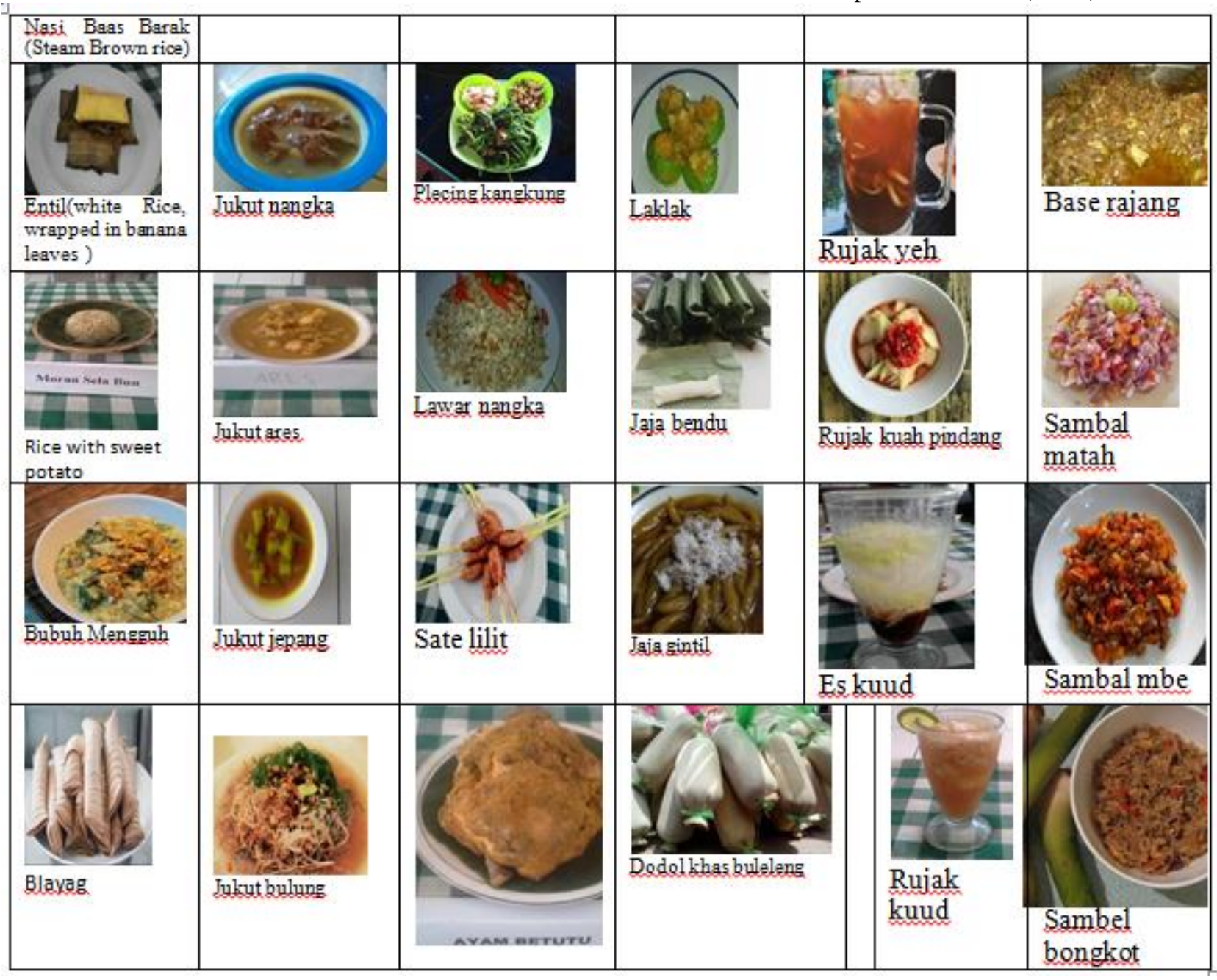

Through the website the Balinese servings whill be widely known by the society and will indirectly be able to be practiced and become the menu in the family circle. This culinary is one of the arts that have to be preserved, since in reality it has been rarely made by mothers who are responsible for serving food for the daily menu. This is 
chicken meat, sea fish, freshwater fish, duck, various types of vegetables;

3) Balinese culinary special spices with the term base genep even consisting of various wet, dry and spices with a certain composition.4) Examples of dishes in the Balinese culinary festival according to classification: Nasi sela/moran, bubuh mengguh, belayag, jukut ares, betutu , sate lilit, lawar, jaja bendu, jaje laklak, jaja gintil, jaja sumping, jaje bendu, rujak yeh, es daluman, rujak kuud, es bir, sambal matah,sambal mbe, sambal bongkot.

\section{REFERENCES}

[1] Ariani, R. P. (2017). Mengenal kuliner bali (1st ed.). PT.RAJAGRAFINDO PERSADA.

[2] Everett, S., \& Aitchison, C. (2008). The Role of Food Tourism in Sustaining Regional Identity: A Case Study of Cornwall, South West England. Journal of Sustainable Tourism. https://doi.org/10.2167/jost696.0

[3] Margi, I.K, Ariani, R, P, Widiastini, N.M.A, Suriani, N. M. (2013). Identifikasi potensi wisata kuliner berbasis bahan baku lokal di Bali. Ilmu Sosial Dan Humaniora, 2(2).

[4] Marsiti, C. I. R. (2005). Hidangan Bali (p. 15). singaraja.

[5] Gisslen, W. 2004. Essential of Professional Cooking, John Wiley \& Sons, Inc, Hoboken, New Jersey.

[6] Londono, M. P. L. 2012. Gastronomy Tourism: an Opportunity For Local Development in Catalonia? AStakeholder Analysis.GmwcTSity of Barecelona, Barcelona-Spain

[7] Okech.Roselyne, N. (2014). Developing Culinary Tourism: The Role of Food as a Cultural Heritage in Kenya. Confrence of Global Busness. https://doi.org/978-1-941505-14-4

[8] Pieniak Z. (2009). Association between traditional food consumption and motives for food choice in six European countries. Elsevier. https://doi.org/doi:10.1016/j.appet.2009.05.019

[9] Putra k.p. dalem A.A. Gede .2013. Pengembangan makanan tradisional bali pada free standing restaurants (fsr), di tanjung benoa. Jurnal Gastronomi Indonesia Volume 2 Nomor 1 Juni 2013 p.1-7

[10] Sirtha, I. . (1998). Aspek Budaya Makanan Tradisional Bali Dalam Menunjang Program Pariwisata. Dinamika Kebudayaan, 1.

[11] Suandra. (1972). Dharma Caruban (Tuntutan Ngebat). Denpasar: CV Kayumas Agung. Suci, dkk. 1986 Pengolahan Makanan. denpasar: CV Kayu Mas.

[12] Sujatha, D.K. 2013. Adaptasi Seni Kuliner Bali menjadi Boga Wisata. Jurnal Gastronomi Indonesia Volume 2 Nomor 1 Juni 2013 p.1-13

[13] Widiastini, A. N. ., Ariani, R. ., \& Andiani, D. . (2014). Pengemasan Makanan Lokal Sebagai 
Produk Wisata Kuliner Di Bali. Jurnal STP Trisakti.

[14] Zainal, A., et.al 2010, Malaysian Gastronomy

Routes as a Tourist Destination. Jurnal Gastronomi, Faculty of Hotel and Tourism Management, Universiti Teknologi MARA, Shah Alam, Selangor, MALAYSIA. 